Chapman University

Chapman University Digital Commons

Education Faculty Articles and Research

Attallah College of Educational Studies

5-5-2018

\title{
Karl Marx and Liberation Theology: Dialectical Materialism and Christian Spirituality In, Against, and Beyond Contemporary Capitalism
}

Peter McLaren

Chapman University, mclaren@chapman.edu

Petar Jandrić

Zagreb University of Applied Sciences

Follow this and additional works at: https://digitalcommons.chapman.edu/education_articles

Part of the Christianity Commons, Comparative Methodologies and Theories Commons, Comparative Philosophy Commons, Economic Theory Commons, Ethics and Political Philosophy Commons, History of Christianity Commons, History of Religions of Western Origin Commons, Other Economics Commons, Other Philosophy Commons, Other Religion Commons, Practical Theology Commons, and the Religious Thought, Theology and Philosophy of Religion Commons

\section{Recommended Citation}

McLaren, P., \& Jandrić, P. (2018). Karl Marx and liberation theology: Dialectical materialism and Christian spirituality in, against, and beyond contemporary capitalism. tripleC: Communication, Capitalism \& Critique, 16(2): 598-607. doi: 10.31269/triplec.v16i2.965

This Article is brought to you for free and open access by the Attallah College of Educational Studies at Chapman University Digital Commons. It has been accepted for inclusion in Education Faculty Articles and Research by an authorized administrator of Chapman University Digital Commons. For more information, please contact laughtin@chapman.edu. 


\section{Karl Marx and Liberation Theology: Dialectical Materialism and Christian Spirituality In, Against, and Beyond Contemporary Capitalism}

\section{Comments}

This article was originally published in tripleC: Communication, Capitalism \& Critique, volume 16, issue 2, in 2018. DOI: $10.31269 /$ triplec.v16i2.965

\section{Creative Commons License}

\section{(c) 1 (1) $(9)$}

This work is licensed under a Creative Commons Attribution-Noncommercial-No Derivative Works 3.0 License.

\section{Copyright}

The authors 


\title{
Karl Marx and Liberation Theology: Dialectical Material- ism and Christian Spirituality in, against, and beyond Con- temporary Capitalism
}

\author{
Peter McLaren* and Petar Jandrić** \\ *Chapman University, Orange, U.S., peter.mclaren1@gmail.com, \\ https://www.chapman.edu/our-faculty/peter-mclaren
}

\begin{abstract}
**Zagreb University of Applied Sciences, Zagreb, Croatia, pjandric@tvz.hr, petarjandric.com
\end{abstract}

\begin{abstract}
This paper explores convergences and discrepancies between liberation theology and the works of Karl Marx through the dialogue between one of the key contemporary proponents of liberation theology, Peter McLaren, and the agnostic scholar in critical pedagogy, Petar Jandrić. The paper briefly outlines liberation theology and its main convergences with the works of Karl Marx. Exposing striking similarities between the two traditions in denouncing the false God of money, it explores differences in their views towards individualism and collectivism. It rejects shallow rhetorical homologies between Marx and the Bible often found in liberation theology, and suggests a change of focus from seeking a formal or Cartesian logical consistency between Marxism and Christianity to exploring their dialectical consistency. Looking at Marxist and Christian approaches to morality, it outlines close links between historical materialism and questions of value. It concludes that the shared eschaton of Marxism and the Christianity gives meaning to human history and an opportunity to change it.
\end{abstract}

Keywords: critical pedagogy, liberation theology, Karl Marx, Christianity, Jesus Christ, eschaton, socialism, Kingdom of God, individualism, collectivism, freedom

\section{Introduction}

Peter McLaren is one of the leading architects of contemporary critical pedagogy and the key force behind its shift from postmodernism "to 'the Marxist-humanist trajectory' spanning from authors with various Marxist tendencies and the neo-Marxism of the Frankfurt School to the original works of Marx" (Jandrić 2017, 160). In 2015, Peter published the ground-breaking book Pedagogy of Insurrection (McLaren 2015) which develops the tradition of liberation theology in and for the context of the 21st century.

Pedagogy of Insurrection builds on two dialectically intertwined pillars: (1) Peter's revolutionary critical pedagogy conceived in the context of the Marxist-humanist trajectory. (2) The Latin American tradition of liberation theology, which McLaren studied through decades of work in countries from Mexico to Venezuela and through works of key historical figures such as Paulo Freire, José Porfirio Miranda, Gustavo Gutiérrez, Leonardo Boff, Jon Sobrino, Hugo Chávez, and others.

During the past years, Peter McLaren and Petar Jandrić co-authored several dialogical pieces (e.g. McLaren and Jandrić 2014; 2015; 2017a; 2017b) dedicated to diverse themes such as the relationships between revolutionary critical pedagogy and information technology, the relevance of Marxism in and for the age of digital reason, and liberation theology. Written in a dialogic format, these conversations expose exchanges between two generations of radical scholars, between a Christian believer 
and an agnostic, and between the Eastern European and the (Latin) American approaches to understanding Marx's legacy. Prepared for the occasion of Karl Marx's 200th birthday, this dialogue draws from our earlier insights and develops Peter's work in Pedagogy of Insurrection to explore links between contemporary Marxian thought and liberation theology and point towards future developments of alternatives to capitalism.

\section{Karl Marx and Liberation Theology}

Petar Jandrić (PJ): What is liberation theology; under which circumstances did it develop ${ }^{1}$ ?

Peter McLaren (PM): Liberation theology, which was born out of the self-theologising of radical Catholic Action communities in America Latina ${ }^{2}$ is systematically opposed to the trenchant conservative politics of white evangelical America in the U.S. who encourage individual charity over economic and transformation and distributive social justice so familiar to many living in the richest country in the world. There arose among both lay persons and clergy within the Catholic Church grievous concern surrounding the economic consequences following the rise of Latin American populist governments of the 1950s and 1960s - especially those of Perón in Argentina, Vargas in Brazil, and Cárdenas in Mexico. In failing to eradicate dependency, poverty and injustice, and carrying the burden of helping both to legitimate and reproduce the power and authority of the capitalist state for over five centuries, liberation theologians considered the Church an egregious failure in its mission to create the Kingdom of God, which they understood in the context of creating a just society on Earth, not some misty paradise beyond the pale of distant clouds, but a world in the here and now. Liberation theology, which coalesced into a movement throughout the 1960s and 1970s, attempted to establish the potential for a return of the role of the Church to the people (similar to the conditions that existed in earliest Christian communities) by nurturing critical-autonomous 'protagonistic agency' 3 among the popular sectors, creating the conditions of possibility for consciousness-raising among peasants and proletarianised multitudes.

PJ: What are the main points of convergence between liberation theology and the works of Karl Marx?

PM: In his 1980 masterwork, Marx against the Marxists: The Christian Humanism of Karl Marx, José Porfirio Miranda, who was educated at the Pontifical Biblical Institute in Rome and who had previously studied sociology in the Frankfurt School, argues that Marx was a Christian humanist who understood the extortionate and unscrupulous characteristics of Christianity and how it was turned into a fraudulent and profiteering caricature of the Gospels when Christianity became the God of empire. Post-Vatican era liberation theologians such as Miranda have recognised and attempted to transcend the role of the Church as reproductive of structural sin (the social relations of capitalist exploitation) to the form of liberating praxis, creating the conditions of possibility to find justice in history. According to Boff, in the first post-Vatican II era (196570):

${ }^{1}$ A more detailed history of liberation theology can be found in (McLaren 2015; McLaren and Jandrić 2017a).

2 There were protestant variants as well; since the 1960s, many variants of liberation theology have emerged such as Jewish Liberation theology, Black Liberation Theology, Feminist Liberation Theology, and Latino/a Liberation Theology.

${ }^{3}$ Coined by Peter McLaren, the term protagonistic agency emphasizes Paulo Freire's (1972) idea of being the subject of history rather than the object of history. 
[...] there arose an extraordinary effort on the part of the clergy to divest itself of the signs of power, to enter more deeply among the people, living their ministry not as someone above and beyond the faithful (priest), but as a principle of encouragement, unity, and service (ordained minister). (Boff 1982, 96)

In the second post-Vatican age (1970-80), campesinos and lay people began to organise themselves into base communities, "where there is an experience of a true ecclesiogenesis" (Ibid.).

Boff $(1982,98)$ contends that the poor serve as the sacrament of Christ, who, "as eschatological judge [...] judges each one according to the love that either liberates from poverty or rejects its plea". The idea of God as eschatological judge permeates Miranda's magisterial works of liberation theology. Rather than antiseptically cleaving liberation theology from Marx's historical-dialectics, as one often discovers in the congeries of opinions of liberation theologians, Miranda sees their intimate connection as a leavening of social justice. Neil Hinnem (2013) is correct in locating the convergence between Miranda's understanding of the biblical perspective on history and Marx's historical-dialectics in Miranda's articulation of orthopraxis and his concept of historical events, the most important event for Miranda being the intervention of Yahweh into human history. As Hinnem (2013) writes:

History is not an evolutionary process: rather, it is punctuated by revolutionary events. For Miranda, these events are the interventions of God in history for the sake of human justice, culminating in the Christ event, ushering all believers in the Kingdom of God. This event leads, consequently, to the Kingdom's underlying hope, its absolute command, that justice be achieved. "In the historical event of Jesus Christ", writes Miranda, "the messianic kingdom has arrived."

For Miranda, the Bible is a subversive document that preached communism long before the time of Karl Marx. Miranda sees much in common between history as liberation from alienation as described by Marx, and the eschaton, or the divine plan for the realisation of the Kingdom of God. ${ }^{4}$

\section{The False God of Money}

PJ: Socialist society may be very close to the Kingdom of God, yet Marxist and Christian methods for achieving the eschaton seem quite different. In the Communist Manifesto, Marx and Engels write "Workers of the World, Unite. You have nothing to lose but your chains!"5; Matthew 5:5 says "Blessed are the meek: for they shall inherit the earth". What about these differences in views to human agency, Peter? What is their relationship to labour?

PM: For Marx, human beings clearly are subjects, subjects of history. The subject of history is related to Marx's concept of living labour, of labour-power, the potential for labouring, the capacity for labour, its possibility and potency. It is living labour that is present in time and throughout human history as possibility, whereas objectified labour serves the means and instruments of production and has no role in liberation from

${ }^{4}$ A more detailed elaboration of concordances between the Christian Kingdom of God and Marx's prophecy of the future socialist society can be found in (McLaren and Jandrić 2017a; 2017b).

${ }^{5}$ We are well aware that this phrase is a popularisation that does not exist in the Communist Manifesto - yet it does adequately describe the dichotomy between Marxist and Christian views to human agency. 
oppression. Marx describes how the capitalist production process makes relationships between persons seem as relationships between things. For Marx, capital grounds all social mediation as a form of value, and that the substance of labour itself must be interrogated because doing so brings us closer to understanding the nature of capital's social universe out of which our subjectivities are created. Because the logic of capitalist work has invaded all forms of human sociability, society can be considered to be a totality of different types of labour. What is important here is to examine the particular forms that labour takes within capitalism. In other words, we need to examine value as a social relation, not as some kind of accounting device to measure rates of exploitation or domination. Consequently, labour should not be taken simply as a 'given' category, but interrogated as an object of critique, and examined as an abstract social structure.

For Marx, the commodity is highly unstable and non-identical. Its concrete particularity (use-value) is subsumed by its existence as value-in-motion or by what we have come to know as "capital". Value is always in motion because of the increase in capital's productivity that is required to maintain expansion. The dual aspect of labour within the commodity (use-value and exchange-value) enables one single commodity money - to act as the value measure of the commodity. Thus, the commodity must not be considered a thing, but a social relationship. You could describe the "soul" of capitalist production as the extraction from living labour of all the unpaid hours of labour that amounts to surplus-value or profit. Marx's analysis of the fetishism of the commodity form bears a strong kinship to the New Testament's references to "false gods". But, as Lebacqz argues:

[...] in spite of its affinity with Marx's analytic methods and social goals, the view of justice provided in liberation theology is not simply a new version of "to each according to need". Justice is not a simple formula for distribution. Justice would not be accomplished merely by offering programs that meet basic needs of the poor. Justice requires the kind of liberating activity that characterizes God's behaviour toward the poor and oppressed [...] there is no separation of "love" and "justice". God's justice is God's love or compassion on those who suffer. God's love is God's justice or liberation of the oppressed. $(1986,107)$

Marx was a humanist, and this is clear in both his private letters but also his published works, but whether he was a Christian humanist as Miranda maintains remains very much an open question. ${ }^{6}$

PJ: Marxism aims at social change through collective action, while Christianity is much more focused to individual development. Obviously, this is not an either-or relationship - as Paulo Freire (1972) would say, collective acts of emancipation are necessarily preconfigured by individual consciousness. What is your take on this tension between (Christian) individualism and (Marxist) collectivism?

PM: The emphasis in Christianity on otherworldliness (don't worry if the bad people are not caught and punished, they will be punished in the afterlife) has often been used as a moral justification for the consecration of deception, either by encouraging passive resistance to exploitation or labelling the unmasking of deeper truths about empire as too subversive, too "anti-American" - a posture that tends to make people unworldly or uncaring about others. Yet, as De La Torre $(2015,162)$ warns: "History demonstrates the futility of simply denouncing unjust social structures for those whom the

\footnotetext{
${ }^{6}$ A more detailed elaboration of this question can be found in (McLaren and Jandrić 2017a).
} 
structures privilege will never willingly abdicate what they consider to be their birthright". The mere moral exercise of political power through passive protest is not a convincing answer since

[...] the idea of the moral exercise of political power ignores what political power is: the state is (not as an abuse but by definition) "the monopoly of legitimate violence". While parts of the state machine may be "very peaceful", the threat of violence, backed up by armed forces, is always presupposed. And the practice of politics, whether in office or in opposition, is always war (mainly class war) carried on by other means. Non-violent politics is a contradiction in terms. (Collier 2001, 104)

So instead of fighting to change the structures of oppression, people either focus on remaking themselves as individuals into better persons (there are plenty of self-help books out there) or they become indelibly indifferent to politics or political change.

Marxism rejects this Cartesian sense of "liberty of indifference" (changing oneself rather than changing the world) and "the preference for autoplastic solutions which underlies it" (Collier 2001, 100). While one is necessarily changed by changing the world (what we call praxis), that does not mean that all attempts to change ourselves are unnecessary or futile - since resistance to oppression requires us to adapt to changing circumstances, and adaptation requires all kinds of strategies of self-change. After all, in his Theses on Feuerbach Marx (1976/1845) writes that: "The coincidence of the changing of circumstances and of human activity or self-changing can be conceived and rationally understood only as revolutionary practice". If we act as if the eschaton has already arrived, and we are preparing for the reign of God, then this is not necessarily a quixotic predicament, but a form of pre-figurative politics.

By letting the reign of God be prefigured in our present lives, whether we image that reign to be a communist society or the Kingdom of God, there is no guarantee that our good actions will bring about its completion - but if we post-date our best ethics to the future communist society or Kingdom of God, then our good actions will, at least, have intrinsic values in themselves. Our organisation and actions should prefigure the socialist revolution or the coming of the Kingdom of God. While it may be true that means do not always resemble ends, Collier argues that "[s]o long as human authority exists, it should as far as possible be organized so that the greatest power serves the least powerful with all its might" which in its contemporary form is called "the dictatorship of the proletariat" (Collier 2001, 122).

PJ: Both the Bible and Marx's works can be read in many different ways - I surely don't need to remind you of historical atrocities which resulted from certain readings of both doctrines... While it is tempting to seek concordances between seminal Christian and Marxist texts, I would like to ask a more fundamental philosophical question: How commensurable are the philosophies of Marxism and Christianity?

PM: Denys Turner (1983) has contributed some important insights with respect to the compatibility of Marxism and Christianity that are worth repeating here. Both Marxism and Christianity are compatible with a materialist theory of history yet hold to a denial of ontological materialism. We are talking here not about a formal or Cartesian logical consistency between Marxism and Christianity but a dialectical consistency.

It is true that there exists no coherent synthesis between Christian doctrines and Marxist theory, but that all the more makes it imperative that we abandon the rhetorical homologies often found in liberation theology - "the anawim [the poor and the oppressed referred to in the Old Testament] become the proletariat, liberation becomes 
redemption politicised, alienation is original sin [....] the priesthood metamorphosed into Lenin's revolutionary leadership" (Turner 1983, 211-212). These homologies are useful, politically, to inspire the struggle of impoverished communities against wellarmed death squads, but they must not be viewed as strict equivalences, since this could lead to uncritical forms of triumphalism.

PJ: I'm glad we're on the same page!

PM: While Marxism and Christianity seem to be incommensurable languages, both are constitutively necessary to explain reality and to understand what forces and relations shape the human condition. Both are part of the praxis of history and can be viewed as historically conditioned action systems, defined by their relationship to historical contingencies. As Turner (1983) reminds us, Marxism requires abolishing the conditions which require it - capitalist exploitation. Similarly, according to Turner, Christianity will realise itself only at the cost of its abolition as Christianity since its realisation will become a fully human reality rather than a sacred reality - a fully socialised humanity and a fully humanised society consisting of love.

However, as Turner (1983) cogently argues, because God is non-identical with the contingencies of any particular form of history, our full humanity can only be known through aspirations for liberation which cannot be realised in practice. We need to secure the conditions of that absence of a presence which we can only symbolise and understand heuristically. We cannot love, we cannot be free, we cannot know God, we cannot know how we can live without oppression, because the Kingdom of God has not been realised; we can only work as Christians and Marxists to secure the conditions of the possibility of loving and living freely. Under capitalism, under the prevailing institutional structures of exploitation, love and freedom can only ever be ideological. We can only anticipate love in its absence, we can never truly see love fulfilled under the conditions of capitalism. In the conditions of bourgeois society, any further claims about love are only ideological. In a world of dehumanised, alienated social relationships, we can only symbolise love through its absence, and so we can say that love, and generosity, and goodness, and Christ are present in this world but present only in the form of their absence.

\section{The Morality of Dialectical Materialism}

PJ: Speaking of the conditions of freedom, and of anticipation, we enter directly into the area of morality. Christian morality is quite theoretically robust, yet, as Rosen $(2000,21)$ says, "the question whether Marx's theory has a moral or ethical dimension is one of the most controversial of all issues of Marx interpretation". What is your take on that question?

PM: Marxism is, in this sense, morality itself, because, as Turner $(1983,215)$ argues: "it consists in the knowledge of what to do given the 'facts'". Marxism is the fundamental science of capitalism and reveals morality in capitalist society to be ideologically bourgeois. Marxism is thus all that morality can be - it represents the outer limits of morality - given today's existing conditions of capitalist exploitation and oppression. Marxism is "the theory and the practice of realizing the conditions of the possibility of morality" (Ibid., 215), while at the same time, it is not possible for Christianity to be regarded as coterminous with Marxism even when Marxism "is demonstrably the scientifically warranted response" to "the conditions of any particular historical epoch" (Ibid., 213). And this is true "even if it follows from the fact that Christianity can know itself and the nature of its praxis only through the Marxist criticism of it" (Ibid., 213). So while Marxism argues about "the impossibility of moral knowledge in capitalist conditions", it exists as a revolutionary form of praxis in that it points out how it is impossible 
for capitalism to conform to its own truth in practice "since conformity is structurally impossible for capitalism" (Ibid., 213).

Christianity attempts to "symbolize the depths of what is to be human in the form of a sacredness, in the form of the refusal to admit what is most fully human could be compatible with the conditions of alienation and exploitation which historically obtain" (lbid., 213). Thus, Christianity recognises love as the point of its praxis but it is a love which, under capitalism, can only be anticipated. Turner makes a prescient point when he argues that the absence of morality in Marxism is not in any sense a "mere amoralism" because it reveals that it is capitalism, not Marxism, which is amoralistic. In other words, Marxism reveals the "platitudinous imperatives, so forthcoming from Christians, to 'love' within conditions of gross and systematic exploitation" (Ibid., 216) and Christianity's "transhistorical pretentiousness" in believing that Christ's presence in history is not historically contingent, that is, not dependent on any particular historical or economic conditions.

Adopting a transcendent morality among Christians is what Turner rejects as Christian "fidelism" which focuses on the Kingdom of God being "within you". This is not to deny the presence of God, but that such presence is not in the form of some supernatural text which has already been written; rather, "the unwritten text is present in the struggle to write it" (Ibid., 219). This is very much like the popular proverb by Antonio Machado that one makes the road by walking (Caminante, no hay camino, se hace camino al andar). Both Marxism and Christianity have the resources within their own traditions for rejecting immorality - for instance, for rejecting meta-moral principles where, for example, communist society is made into a moral absolute or Christianity is presented as an already written moral text to which only Christians or particularly enlightened Christians have access.

According to Turner, Marx rejected theism as false, because it "supposes an opposition between God and man" (Ibid., 165) and he criticises atheism "because it accepts the terms which theism lays down and can speak of man only indirectly, that is, via the negation of theism" (Ibid., 165). Marx rejected the theologically and politically conservative Christianity of his day, as well as the radical Christianity that made its appearances throughout his lifetime. Marx claims that questions pertaining to the existence of God arise only among those who fail to understand their own natural human origins. Turner recognised that Marx rejected contemporary immanentist theologies because he viewed them as a partial regression to negative atheism itself. While Marx rejected negative atheism, Turner does not take that to mean Marx was not an atheist.

PJ: I could somehow swallow that Marx was not a (complete) atheist, but it cannot be disputed that he was very anti-clerical. How does liberation theology, with its close relationships to the Church, absorb Marx's negativity towards its own being?

PM: Marx was anti-clerical, and so would any rational person be during the time of Marx who recognised that Jesus was the antithesis of clericalism, a clericalism whose world-denying conciliar prohibitions infected by monarchism and paternalism, disallowed justice for all. It was a temporal power that germinated autocracy and was leavened by obedience to a hierarchy that almost always sided with the imperial and structural intentionality of the state. It was clear to Marx and like-minded others that the ecclesiology that developed from the law, especially canon law, gave the papacy unrestricted power over the laity, resulting in a religious hubris of unrelenting fidelity to empire. It had ripped away from early Christianity sanctioned disobedience to imperial law. Now it demanded compliance to the dictatorship of the ruling class and its despotic commands often leading to brutishness, cruelty and unvarnished terror, to prioritising sacred laws over human welfare and making the Law of Christ coextensive with the 
Law of Empire and its imperial covenant directed at capital accumulation by dispossession.

In liberation theology, however, there must be a principled intransigence towards authoritarian power rather than a creative adaptation to it, an ecclesiogenesis ${ }^{7}$ that lives in dialectical tension between the pneumatological ${ }^{8}$ and doctrinal aspect of the church and the base of the Church of the Poor. The Church proclaims a Kingdom of God that it can never put into practice, similar to capitalism that installs the very conditions (wage labour, value augmentation, social relations of production) under which wealth and prosperity are available only to a few. Yet both cannot abandon the teachings they cannot follow.

PJ: Marx was a scientist, and his worldview is based on dialectical materialism. Liberation theology is religious, and its worldview is based on faith. How do you reconcile these radically different approaches to reality?

PM: Today in our efforts to create a society constructed upon principles of social justice we have approached our projects as scientifically distilled data - big data serves both as our compass and our destination. But allegiance to data removes the consensus-generating process that is part of collective reflection and systematic rationality, as Miranda explains so well. Interpersonal dialogue has to be part of the object of study and rational reflection - since relations between people are the basis of the relations between things. We can't forget this. As Miranda $(1980,306)$ notes, the "communitarian process leading to consensus can evade the arbitrariness or naiveté of extrascientific motives only if we, in all frankness, realize that dialogic discussion does exist, that it is moral in character, and that it is thus a matter of conscience". Without this consideration articulated by Miranda, and reflected in Paulo Freire's (1972) Pedagogy of the Oppressed, we will etherise the role that our conscience must play and fall prey to corruption and self-interest.

We can't separate norms and facts, facts and value, for this expunges meaning from history, and both Marx and the teachings of the gospels recognise this. As Miranda $(1980,307)$ notes, "The eschaton of Marx, which is the same as that of the gospel, is what gives meaning to history". The project of immanentising the eschaton is one that has historically struck fear in the hearts of conservatives who use the term pejoratively because it refers to attempts to bring about the Kingdom of God in the immanent world. The conservatives equate this with socialism, communism, anti-racism and even Nazism. But reading the Gospel from below mandates that such a project is already in the making, with the intervention of Christ into human history. It is rejected by conservatives for fear of the rise of totalitarianism. But at the root of such fear is that panic in the hearts of those who stand to lose their wealth and status should a state of egalitarianism and equality be achieved.

PJ: What is the main message of Marx's work for liberation theology positioned in, against, and beyond contemporary capitalism (cf. Holloway 2016)?

PM: All of us can become blinded by virtue of our own interests, whether we are atheists, agnostics, Christians, Christian communists, or members of other religious faiths. For example, the capitalist does not realise that what is sold in the transaction between the capitalist is labour-power, not labour - sold at its exchange value,

\footnotetext{
${ }^{7}$ The term 'ecclesiogenesis' is used by liberation theologian Leonardo Boff to describe the new ecclesiological experience within the Basic Christian Communities created in Latin America in which attempts are made by popular constituencies to create authentic Christian communities. Participants see this as creating a new form of church outside of the institutional structures of the traditional Catholic hierarchy (see Boff 1986).

${ }^{8}$ In Christianity, the term 'pneumatology' refers to the study of the Holy Spirit.
} 
and so the capitalist is wilfully blinded to the fact that labour-power produces much more than it is worth simply as exchange value (the labourer works much more than it takes to reproduce his or her own necessities for survival) and operates out of a motivated amnesia that the capitalist has been stealing surplus value from his workers. The Christian and the capitalist rarely think deeply about Marx's notion of value, and both adhere to the empiricist expression "price of labour", which hides the fact that the wage system is, in reality, a form of slavery. This, according to Marx, is an epistemological issue as much as a moral issue. As Miranda points out, Marx did not adhere to a materialist dogmatism that limited epistemology to social class. He recognised that the very mechanism of cognition itself is ideological, and that there are moral values embedded in the process of cognition - that within the apologetics and empiricist ideologies of economists there exists hidden interests which he viewed as ideological.

It is worth remembering Miranda's $(1980,303)$ insight: "Empiricism sticks to things. Marx dissolves things into relations between persons because conscience is not troubled by any moral obligation whatsoever when it confronts things". Hence, it is important for both Christians and Marxists to remember that exploitation and oppression can only be overcome by a sincere willingness to know the truth. Yes, truth is always partial, contingent and contextual, but it can be known. Which is why I believe the work of Marx is so essential to Christianity and why liberation theology needs to be continually reinvented for the current times, especially after such brutal efforts by the Reagan administration and Pope John Paul II to silence it, and efforts by right-wing dictatorships throughout Latin America to crush it by murdering priests and exponents of the Church of the Poor in the 1970s and 1980s. Today, especially today, the world needs liberation theology, which, by the way, is not restricted to Christianity or Christians but to all those who seek justice in these exceedingly brutal times.

\section{References}

Boff, Leonardo. 1986. Ecclesiogenesis: The base communities reinvent the church. Maryknoll, NY: Orbis Books.

Boff, Leonardo. 1982. Francis of Assisi: A Model of Human Liberation. Translated by J. W. Diercksmeier. Maryknoll, NY: Orbis Books.

Collier, Andrew. 2001. Christianity and Marxism: A Philosophical Contribution to their Reconciliation. London: Routledge.

De La Torre, Miguel. 2015. The Politics of Jesús: A Hispanic Political Theology. Lanham: Rowman and Littlefield.

Freire, Paulo. 1972. Pedagogy of the Oppressed. Harmondsworth: Penguin Education Specials.

Holloway, John. 2016. In, against, and beyond Capitalism: The San Francisco Lectures. Oakland, CA: PM Press/Kairos.

Jandrić, Petar. 2017. Learning in the Age of Digital Reason. Rotterdam: Sense.

Lebacqz, Karen. 1986. Six Theories of Justice: Perspectives from Philosophical and Theological Ethics. Minneapolis: Augsburg.

Marx, Karl. 1976/1845. Theses on Feuerbach. In Marx-Engels-Collected-Works (MECW), Volume 5. Accessed January 3, 2018. http://marxists.anu.edu.au/archive/marx/works/1845/theses/original.htm.

Marx, Karl and Friedrich Engels. 1976/1848. The Communist Manifesto. In Marx-Engels-Collected-Works (MECW), Volume 6. Accessed January 3, 2018. https://www.marxists.org/archive/marx/works/1848/communist-manifesto/index.htm.

McLaren, Peter. 2015. Pedagogy of Insurrection: From Resurrection to Revolution. New York: Peter Lang. 
McLaren, Peter and Petar Jandrić. 2017a. From Liberation to Salvation: Revolutionary critical pedagogy meets liberation theology. Policy Futures in Education 15 (5): 620-652.

McLaren, Peter and Petar Jandrić. 2017b. Peter McLaren's Liberation Theology: Karl Marx Meets Jesus Christ. In Leadership Lessons: Great Thinkers on Equity, Justice and Education, edited by Jeffrey S. Brooks and A. Normore, 39-48. New York: Teachers College Press.

McLaren, Peter and Petar Jandrić. 2015. The Critical Challenge of Networked Learning: Using Information Technologies in the Service of Humanity. In Critical Learning in Digital Networks, edited by Petar Jandrić and Damir Boras, 199-226. New York: Springer.

McLaren, Peter and Petar Jandrić. 2014. Critical Revolutionary Pedagogy is Made by Walking: In a World where Many Worlds Coexist. Policy Futures in Education 12 (6): 805-831.

Miranda, José Porfirio. 1980. Marx against the Marxists: The Christian Humanism of Karl Marx. Translated by J. Drury. Maryknoll, NY: Orbis Books.

Neil Hinnem. 2013. Marx and the Bible. The Oxford Left Review 11: 31-37.

Rosen, Michael. 2000. The Marxist Critique of Morality and the Theory of Ideology. In Morality, Reflection and Ideology, edited by Edward Harcourt, 21-43. Oxford: Oxford University Press.

Turner, Denys. 1983. Marxism and Christianity. Oxford: Blackwell.

\section{About the Authors}

\section{Peter McLaren}

Peter McLaren is a Distinguished Professor in Critical Studies at Chapman University, USA, where he is Co-Director of the Paulo Freire Democratic Project. Professor McLaren is the author and editor of nearly 50 books and hundreds of professional publications on education and social justice. His writings have been translated into over 20 languages. One of Professor McLaren's recent awards includes the Outstanding Educator in America Award presented to him by the Association of Educators of Latin America and the Caribbean.

\section{Petar Jandrić}

Petar Jandrić is a Professor in Digital Learning and Programme Director of BSc (Informatics) at the Zagreb University of Applied Sciences (Croatia), and visiting Associate Professor at the University of Zagreb (Croatia). His research is focused to trans-disciplinary collaborations at the intersections between critical pedagogy and digital cultures. Petar published six books, dozens of scholarly articles and chapters, and numerous popular articles. His writings have been published in several languages. 